\title{
Protecting internally displaced persons: The value of the Kampala Convention as a regional example
}

\author{
Adama Dieng* \\ Adama Dieng is UN Under-Secretary-General and Special \\ Adviser on the Prevention of Genocide. He is the former \\ Registrar of the International Criminal Tribunal for Rwanda.
}

\section{Abstract}

This article examines the value of the African Union Convention for the Protection and Assistance of Internally Displaced Persons in Africa (Kampala Convention) in the general quest for the regional and global protection of internally displaced persons (IDPs). It contends that the absence of a globally binding legal instrument for the protection of IDPs underlines the importance of the Kampala Convention and the possible contribution it can make to global and regional efforts to create a binding legal framework for the protection of IDPs. While recognizing some challenges that may impact the full implementation of the Convention, the article concludes by noting its various positive elements that are invaluable in overall efforts to create a comprehensive global legal framework to enhance protection of IDPs.

Keywords: African Union, IDPs, international human rights law, international humanitarian law, international law, Kampala Convention.

* The views expressed in this article are those of the author and do not represent the official position of the United Nations. The author would like to thank Volker Türk and Charles Riziki Majinge for their useful comments and insights. Any errors or omissions are those of the author. 


\section{Introduction}

In October 2009, the African Union (AU, formerly the Organisation of African Unity, OAU) adopted the African Union Convention for the Protection and Assistance of Internally Displaced Persons in Africa (Kampala Convention) as a normative framework to protect and assist internally displaced persons (IDPs) on the continent. ${ }^{1}$ The adoption of this Convention was largely dictated by the reality that Africa is a region with large-scale internal displacement. ${ }^{2}$ This article argues that the decision to adopt the Kampala Convention was inspired by the need to go beyond the 1998 Guiding Principles on Internal Displacement (Guiding Principles) earlier developed by the United Nations (UN), in order to guarantee protection of the displaced on the continent. Perhaps more compelling was the fact that Africa is disproportionately affected by the challenge of displacement, and as such it was in the interest of African countries to establish a permanent framework within which they could cooperate in addressing this phenomenon. The Convention was a bold and landmark measure to create an instrument defining the rights and responsibilities of IDPs and States within the African context. ${ }^{3}$

The underlying goal of this article is to examine the challenge of internal displacement and to look at how the Kampala Convention addresses this challenge and could potentially serve as an example for the adoption of a future global legal framework for IDPs or as a model for other regions with large-scale internal displacement. It is argued here that internal displacement presents a unique challenge because it more often than not entails interventions by external actors that are called upon when humanitarian needs arising from the sudden onset of large-scale internal displacement exceed the capacity of a single State to provide protection and assistance to the displaced which would ideally be provided for by that State.

Further, this article seeks to examine how the Convention allocates and distinguishes obligations toward States, IDPs and non-State actors, and how the international community can ensure that its activities do not serve as a basis to

1 African Union Convention for the Protection and Assistance of Internally Displaced Persons in Africa, 22 October 2009 (entered into force 6 December 2012). For further work on the Kampala Convention, see Chrysanthus Ache and Charles Riziki Majinge, "International Law as a Mechanism to Advance the Rights of the Displaced in Africa: Examining the Role of the African Union Convention for the Protection and Assistance of the Internally Displaced Persons in Africa", African Yearbook of International Law, Vol. 18, No. 1, 2010. See also Marina Sharpe, "Engaging with Refugee Protection? The Organization of African Unity and African Union since 1963", New Issues in Refugee Research Series, UNHCR Research Paper No. 226, 2011.

2 At the end of 2015, the Office of the UN High Commissioner for Refugees (UNHCR) estimated that Africa hosted close to $30 \%$ of the global total of displaced persons. See: www.unhcr.org/figures-at-a-glance.html (all internet references were accessed in April 2017). See also: www.internal-displacement.org/ publications/2016/africa-report-2016/. The statistics do suggest that today Africa is second only to the Middle East in internal displacement caused by conflict, at 2.4 million people, plus 1.1 million caused by disasters.

3 Won Kidane, "Managing Forced Displacement by Law in Africa: The Role of the New African Union IDPs Convention", Vanderbilt Journal of Transnational Law, Vol. 44, No. 1, 2011, p. 6. See also Guy S. Goodwin-Gill, "The Movements of People between States in the 21st Century: An Agenda for Urgent Institutional Change", International Journal of Refugee Law, Vol. 28, No. 4, 2016. 
justify the failure or unwillingness of the concerned State to discharge its obligations towards its own citizens. These questions are crucial because they will help explain the framework of international assistance towards IDPs and how the international community could complement the concerned State's efforts to provide assistance and protection to its own citizens. They will further help in clarifying the fundamental character of IDPs as the primary responsibility of their respective governments.

The Charter of the United Nations (UN Charter) ${ }^{4}$ and international customary law have unequivocally reaffirmed the right of States to determine their internal affairs without outside interference, ${ }^{5}$ yet the failure of countries to protect both their people and their frontiers has consistently challenged this doctrine. This failure could be attributed to State collapse, weak governance structures, protracted conflicts and/or the inability of States to exercise sovereignty over part or the whole of their territories. It is these challenges which provide a compelling need for the international community to extend protection to those unable to avail themselves of protection from their own governments within their countries. This argument is made in light of the fact that international law recognizes the responsibility of the international community to provide protection and assistance to those who may not be able to avail themselves of the same from their governments. ${ }^{6}$

The article is divided into six main sections. The first section examines the existing normative gap for protecting IDPs, while the second discusses the role and impact of the Guiding Principles. The third section offers an overview of efforts leading up to the Kampala Special Summit where the AU instrument on IDPs was adopted, followed by a reflection on its most prominent features. The fifth section provides arguments on how the Kampala Convention can serve as an example for a global IDP legal protection model. The article concludes with suggestions on measures that could help enhance protection of IDPs through international solidarity and a comprehensive global protection legal instrument.

\section{The existing normative gap for protecting the IDPs}

IDPs are bona fide citizens or habitual residents within their own countries with a legitimate claim to all existing rights/protection provided for by the international

4 Charter of the United Nations, 1 UNTS XVI, 24 October 1945 (UN Charter).

5 Ibid., Art. 2. See, generally, Paul M. Powers, "Unilateral Humanitarian Intervention and Reform of the United Nations Veto: A Pilot Program Aimed towards International Peace and Increased Security Worldwide", Homeland \& National Security Law Review, Vol. 4, No. 1, 2016. See also James Crawford, The Creation of States in International Law, 2nd ed., Oxford University Press, Oxford, 2007; Christine Chinkin, "Peace and Force in International Law", Studies in Transnational Legal Policy, Vol. 25, 1993, pp. 203-204.

6 Noële Crossley, Evaluating the Responsibility to Protect: Mass Atrocity Prevention as a Consolidating Norm in International Society, Routledge, New York, 2016. See also Roland Paris, "The 'Responsibility to Protect' and the Structural Problems of Preventive Humanitarian Intervention", International Peacekeeping, Vol. 21, No. 5, 2014; Eric Heinze, Waging Humanitarian War: The Ethics, Law, and Politics of Humanitarian Intervention, State University of New York Press, Albany, NY, 2009. 
human rights law (IHRL) and, in situations of armed conflict, international humanitarian law (IHL) treaties to which their countries may be party. ${ }^{7}$ The claim that IDPs are protected under the IHRL regime is concretized by the fact that human rights norms and values apply to all individuals without distinction and in almost all circumstances. ${ }^{8}$ The argument regarding the lack of an international legal protection regime for IDPs is premised on the fact that despite being in their own countries, IDPs hardly enjoy these rights as spelled out in IHRL or IHL instruments precisely because of their displacement and inadequate State protection. In other words, when people are on the move, it is difficult to ensure that their rights are protected, hence necessitating a specific legal framework to protect them. ${ }^{9}$

The absence and impact of an internationally binding legal regime for the protection of IDPs was apparent despite widely held views that as long as persons are exposed to humanitarian crisis or the risk of human rights atrocities, even within their own countries, they should be a legitimate concern of the international community. ${ }^{10}$ Unlike refugees, who are provided with a special protection regime under the 1951 Convention relating to the Status of Refugees ${ }^{11}$ and its subsequent Protocol $^{12}$ (including the 1969 OAU Convention Governing the Specific Aspects of Refugee Problems in Africa (OAU Convention), ${ }^{13}$ which provides a minimum "safety net" for refugees), IDPs do not have any legal framework dedicated to their protection. This directly imperils their chances of attracting international protection and assistance. ${ }^{14}$ Closer examination reveals that IDPs, despite their non-recognition under international law as a legitimate concern that would warrant the creation of a humanitarian organization like the Office of the UN High Commissioner for Refugees (UNHCR), experience tragedy similar to refugees.

The negative impacts of the lack of a specific institution or convention with a global mandate to address the challenge of IDPs have been significant. ${ }^{15}$ As part of its humanitarian reforms, the UN made efforts through the "cluster approach" to

7 Elizabeth Ferris, "International Responsibility, Protection and Displacement: Exploring the Connections between R2P, Refugees and Internally Displaced Persons", Global Responsibility to Protect, Vol. 8, No. 4, 2016. See also Catherine Phuong, The International Protection of the Internally Displaced Persons, Cambridge University Press, Cambridge, 2006, p. 39; Addis Barega Birganie, "An African Initiative for the Protection of the Rights of the Internally Displaced Persons", Human Rights Law Review, Vol. 10, No. 1, 2010.

8 E. Ferris, above note 7.

9 C. Phuong, above note 7, p. 43.

10 Gareth Evans, The Responsibility to Protect: Ending Mass Atrocity Crimes Once and For All, Brookings Institution Press, Washington, DC, 2008, p. 52.

11 Convention relating to the Status of Refugees, 189 UNTS 150, 28 July 1951 (entered into force 22 April 1954).

12 Protocol relating to the Status of Refugees, 606 UNTS 267, 31 January 1967 (entered into force 4 October 1967).

13 OAU, Convention Governing the Specific Aspects of Refugee Problems in Africa, 1001 UNTS 45, 10 September 1969 (entered into force 20 June 1974).

14 Francis M. Deng, "The Global Challenge of Internal Displacement”, Washington University Journal of Law and Policy, Vol. 5, No. 141, 2001.

15 Roberta Cohen and Francis M. Deng, Masses in Flight: The Global Crisis of Internal Displacement, Brookings Institution Press, Washington, DC, 1998, pp. 1-8. 
enhance assistance and protection for IDPs. Under this approach, three clusters were established. UNHCR was tasked with overseeing protection, camp management, camp coordination and emergency shelter, the UN International Children's Emergency Fund was tasked with water, sanitation and nutrition, the World Food Programme focused on logistics, and the UN Development Programme dealt with recovery. ${ }^{16}$ The allocation of responsibilities among these organizations was closely aligned to their core mandates, such that they would not have to deviate or seek new mandates to perform these responsibilities. By adopting this approach, it was hoped that IDPs would receive necessary assistance and that existing protection lacunae would be addressed.

However, this approach did not yield the envisaged outcome. Key flaws were seen in having a lesser role for non-governmental organizations that tend to do the "actual" work in the field, and in the tendency to focus on emergent crises giving less attention to protracted crises. In the words of one former senior Western diplomat commenting on the role of the cluster approach: "Agencies are supposed to act as 'co-heads'. In practice, however, 'co-heads' means 'no-heads'."17

While, in general, international law recognizes the sovereign right and responsibility of States to protect citizens within their own borders, political, economic and social realities have inhibited this capability. In some cases, while a government may be in power, its ability to protect its citizens and exercise sovereign authority across its entire territory is constrained by political instabilities and, especially, various armed groups that equally control some parts of the territory. As a consequence, millions of citizens in some countries have found themselves trapped between rebels or militias and government forces fighting against each other, ultimately depriving civilians - in need of protection - of their safety and well-being. It has been argued that an international treaty to address the challenges of IDPs would be an infringement on State sovereignty, whereby rich and powerful States would have an excuse to intervene in the domestic affairs of weaker countries. ${ }^{18}$ Indeed, it is on the basis of the sovereign equality of States and non-intervention principles traditionally adhered to by all countries - that some countries have on different occasions rejected international assistance, even to the potential detriment of millions of their citizens. ${ }^{19}$

International law has reaffirmed that States have certain obligations towards their citizens and that they cannot treat their populations as they wish

16 Dennis McNamara, "Humanitarian Reform and New Institutional Responses", Forced Migration Review/ Brookings-Bern Special Issue, 2006.

17 See, generally, Marina Mattiolo, "Protection of IDPs in Armed Conflict in 2014", in Annyssa Bellal (ed.), The War Report: Armed Conflict in 2014, Oxford University Press, Oxford, 2015.

18 For the possible tension between civilian protection and IDPs, see Roberta Cohen, "Reconciling R2P with IDP Protection", Global Responsibility to Protect, Vol. 2, No. 1, 2010.

19 Jurgen Haacke, "Myanmar, the Responsibility to Protect, and the Need for Practical Assistance", Global Responsibility to Protect, Vol. 1, No. 2, 2009. See also Stuart Ford, "Is the Failure to Respond Appropriately to a Natural Disaster a Crime Against Humanity: The Responsibility to Protect and Individual Criminal Responsibility in the Aftermath of Cyclone Nargis", Denver Journal of International Law and Policy, Vol. 38, No. 2, 2009-10; Alison McCormick, "From Sovereignty to Responsibility: An Emerging International Norm and its Call to Action in Burma”, Indiana Journal of Global Legal Studies, Vol. 18, No. 1, 2011. 
with impunity in the name of sovereignty. ${ }^{20}$ States are required to extend protection to such vulnerable groups of people displaced within their countries without discrimination. ${ }^{21}$ Indeed, it is on the basis of this recognition of State obligation that the doctrine of responsibility to protect has emerged. ${ }^{22}$ The doctrine essentially compels States to take measures to guarantee the protection of their populations against war crimes, crimes against humanity and genocide. ${ }^{23}$ This is an obligation that also extends to the protection of IDPs from human rights violations and atrocities.

\section{The 1998 Guiding Principles on Internal Displacement}

In 1998, recognizing the growing challenge of IDPs worldwide and the lack of a comprehensive legal protection mechanism, the UN Human Rights Commission, a subsidiary organ of the General Assembly, adopted the Guiding Principles on Internal Displacement. ${ }^{24}$ These principles were also noted by the General Assembly in its resolution supporting the work of UNHCR. ${ }^{25}$ Essentially, the Guiding Principles identify and reinforce the intersection of specific IHRL and IHL guarantees for IDPs. ${ }^{26}$ They explicitly recognize the right not to be arbitrarily displaced and spell out in detail the rights of those who are displaced. They further reaffirm that a government cannot deny access to international humanitarian organizations providing assistance to IDPs if it is unable or unwilling to provide the necessary assistance itself, and underline the right of IDPs to either return voluntarily to their homes or places of habitual residence or to resettle voluntarily in another part of the country. As Roberta Cohen has noted:

While acknowledging that primary responsibility rests with national authorities, the Guiding Principles recast sovereignty as a form of national responsibility toward one's vulnerable population with a role provided for the international

20 Francis M. Deng, "From 'Sovereignty as Responsibility' to the "Responsibility to Protect", Global Responsibility to Protect, Vol. 2, No. 4, 2010. See also Francis M. Deng, "The Evolution of the Idea of 'Sovereignty as Responsibility", in Adekeye Adebajo (ed.), From Global Apartheid to Global Village: Africa and the United Nations, University of KwaZulu-Natal Press, Scotsville, 2009; Luke Glanville, "The Antecedents of 'Sovereignty as Responsibility", European Journal of International Relations, Vol. 17, No. 2, 2011.

21 Tom J. Farer, "Humanitarian Intervention before and after 9/11: Legality and Legitimacy", in J. L. Holzgrefe and Robert O. Keohane (eds), Humanitarian Intervention: Ethical, Legal and Political Dilemmas, Cambridge University Press, Cambridge, 2007, pp. 55-56.

22 International Commission on Intervention and State Sovereignty, The Responsibility to Protect, International Development Research Centre, Ottawa, December 2001.

23 For extensive discussion on this see, Sarah Teitt, "Sovereignty as Responsibility", in Tim Dunne and Christian Reus-Smit (eds), The Globalization of International Society, Oxford University Press, Oxford, 2017.

24 UN Human Rights Commission, Guiding Principles on Internal Displacement, UN Doc. E/CN.4/1998/53/ Add.2, 11 February 1998.

25 UNGA Res. 53/125, 12 February 1999, para. 16.

26 Walter Kälin, "Supervising the 1951 Convention Relating to the Status of Refugees: Article 35 and Beyond", in Erika Feller et al. (eds), Refugee Protection in International Law: UNHCR's Global Consultations on International Protection, Cambridge University Press, Cambridge, 2003, p. 634. 
community when governments [do] not have the capacity or willingness to protect their uprooted populations. ${ }^{27}$

While the Guiding Principles do not constitute a legally binding multilateral treaty, they have informed national and regional normative frameworks, the Kampala Convention being among the most significant. ${ }^{28}$

Today, it is widely accepted that the Guiding Principles remain the major international legal protection regime for IDPs at the global level. ${ }^{29}$ The greatest achievement underscored by the Guiding Principles is the internationalization of the internal situation of displaced persons by bringing together the broad principles of IHRL and IHL applicable especially to persons displaced within States. ${ }^{30}$ The Principles have been widely acknowledged by different countries and institutions as the legitimate basis for advancing the protection of IDPs.

For example, the UN General Assembly sees the protection of IDPs as having been strengthened by identifying, reaffirming and consolidating specific standards, in particular through the Guiding Principles. The General Assembly has further recognized the Principles as an important international framework for the protection of IDPs. ${ }^{31}$ In the World Summit Outcome Document, the Principles were recognized as an important international framework for the protection of IDPs, and members resolved to take effective measures to increase protection of and assistance for IDPs. ${ }^{32}$ The UN Human Rights Commission has termed the Guiding Principles as "an important tool for dealing with situations of internal displacement". Indeed, the Commission commended States, UN agencies and regional organizations for applying the Principles as standard norms. ${ }^{33}$

While it is clear that the Guiding Principles have gained wide recognition by different international institutions involved in the protection of IDPs, it is argued that they do not constitute a binding legal instrument. This argument is made in light of the fact that, unlike treaties or soft-law instruments (such as declarations, resolutions or recommendations by international organizations such as the General Assembly), they were not negotiated by States, but were rather prepared by a team of experts who were not representing sovereign States that are normally the principle subject of negotiating and complying with international law. ${ }^{34}$ As such, the implementation and observance of the Guiding

27 Roberta Cohen, "The Guiding Principles on Internal Displacement: An Innovation in International Standard Setting", Global Governance, Vol. 10, No. 4, 2004.

28 Susan Martin, "New Models of International Agreement for Refugee Protection", Journal on Migration and Human Security, Vol. 4, No. 3, 2016. See also C. Ache and C. R. Majinge, above note 1, pp. 427-431.

29 Chaloka Beyani, "The Elaboration of a Legal Framework for the Protection of Internally Displaced Persons in Africa", Journal of African Law, Vol. 50, No. 2, 2006.

30 Ibid.

31 See UNGA Res. 60/168, "Protection of and Assistance to Internally Displaced Persons", 7 March 2006, para. 8 .

32 UN General Assembly, 2005 World Summit Outcome Document, UNGA Res. A/RES/60/1, 24 October 2005, para. 132.

33 UN Human Rights Commission Res. 2003/51, E/CN.4/RES/2003/51, para. 7.

34 Phil Orchard, "Protection of Internally Displaced Persons: Soft Law as a Norm-Generating Mechanism", Review of International Studies, Vol. 36, No. 2, 2010. 
Principles rests on the goodwill of States within whose borders IDPs are found. Yet, despite their non-binding nature, the Guiding Principles were drafted in a way that carefully restates existing international law with a view to making more general norms applicable to the specific situation of internal displacement. ${ }^{35}$ On the basis of this fact, they can be considered to constitute minimum international standards for the protection of IDPs. ${ }^{36}$

Refugees benefit from an established international legal regime providing for their protection, and an international agency to advocate for and advance their interests. IDPs, on the other hand, do not have such an agency. The Guiding Principles do not provide for the establishment of an agency to cater for IDPs, leaving them at the centre of a protection vacuum. Indeed, this protection gap was identified earlier by Dr Francis Deng, the first UN Special Representative of the Secretary-General for IDPs at the beginning of his mandate in 1992. In his first report, he suggested the creation of a specialized agency for IDPs or designation of an existing agency to assume full responsibility for IDPs. Concerning both ideas, Dr Deng contended that a broader consensus within the UN member States had emerged, to the effect that the problem is too big for one agency and requires the collaborative capacities of the international system. ${ }^{37}$ Explaining the reluctance of the international community to consider his proposal, Dr Deng contended that the overriding reason was the lack of political will within the international community to create an agency for IDPs. ${ }^{38}$ This lack of political will can be attributed to the unwillingness of countries to allow interference in matters they consider domestic. Additionally, the acceptance of this proposal would have compelled countries to provide additional resources to fund this institution.

\section{The road to the Kampala Convention}

Despite the provision in the 1969 OAU Convention which categorically prevented member States from interfering in domestic affairs of other countries, ${ }^{39}$ the OAU demonstrated over time its commitment to addressing the question of internal displacement on the continent. ${ }^{40}$ Against this recognition, the OAU and its successor the AU progressively adopted ambitious strategies to address the protection and assistance challenges facing IDPs in Africa. For example, in the

35 Walter Kälin, “The Role of the Guiding Principles on Internal Displacement”, Forced Migration Review, Supplement, October 2005. See also Roberta Cohen, "Lessons from the Development of the Guiding Principles on Internal Displacement", Forced Migration Review, No. 45, 2014.

36 Ibid.

37 R. Cohen and F. M. Deng, above note 15.

38 Ibid.

39 Ben Kioko, “The Right of Intervention under the African Union's Constitutive Act: From NonInterference to Non-Intervention", International Review of the Red Cross, Vol. 85, No. 852, 2003, pp. 813-815.

40 Patrick Tigere and Rita Amukhobu, “The African Union's Institutional Framework for Responding to Forced Displacement in Africa", Conflict Trends, Vol. 2005, No. 3, 2005. 
early 1990s, the African Commission on Human and Peoples' Rights (ACHPR) organized a seminar on the protection of African refugees and IDPs in Harare, Zimbabwe. ${ }^{41}$ The conclusion of this seminar recognized inter alia that the plight of African refugees and IDPs is a flagrant violation of human dignity and basic human rights, and that such violations constituted a permanent threat to the orderly and peaceful development of Africa. The ACHPR called upon the international community to extend its wholehearted solidarity in order to help African States assume their responsibility to address the root causes and find durable solutions for the plight of refugees and IDPs. ${ }^{42}$ This conclusion demonstrates two crucial aspects: the recognition that the challenge of forced displacement constituted a threat to the peace and development of the continent, and the responsibility of African countries to address this challenge, either on their own or with assistance from the international community.

It is on the basis of this recognition that the Constitutive Act of the AU (AU Constitutive Act $)^{43}$ categorically recognizes the responsibility of States to promote and protect human and peoples' rights in accordance with the African Charter on Human and Peoples' Rights and other relevant human rights instruments. ${ }^{44}$ The AU Constitutive Act also requires member States to promote cooperation in all fields of human activity in order to raise the living standards of the African people. All these provisions are relevant to the protection and assistance of IDPs precisely because they reaffirm IDPs' status as citizens in their respective countries, with the attending rights and obligations of citizenship.

The resolve of African countries to address the challenge of IDPs through policy and institutional measures at the highest level of the AU was reflected in the appointment of ACHPR Commissioner Bahame Nyanduga as a Special Rapporteur on Refugees, Asylum Seekers and IDPs in Africa. ${ }^{45}$ Commissioner Nyanduga was tasked with a specific mandate. ${ }^{46}$ Concretizing the efforts of Commissioner

41 Conclusion of the Seminar on Protection of African Refugees and IDPs, Harare, February 1994, reprinted in 7th Annual Activity Report of the African Commission on Human and Peoples' Rights, ACHPR/RPT/ 7th, 1993-94.

42 Ibid.

43 OAU, Constitutive Act of the African Union, 1 July 2000.

44 See Bahame Nyanduga, "Addressing IDP Protection in Africa”, Forced Migration Review, Supplement, October 2005.

45 ACHPR Res. 72(XXXV)04, providing for the establishment of the mechanism of Special Rapporteur on Refugees, Asylum Seekers and Internally Displaced Persons in Africa.

46 ACHPR Res. 72(XXXVI)04, adopted at Dakar during the 36th Ordinary Session of the Commission, 2004. Nyanduga's tasks included seeking, receiving, examining and acting upon information on the situation of refugees, asylum-seekers and IDPs in Africa; helping member States of the AU to develop appropriate policies, regulations and laws for the effective protection of refugees, asylum-seekers and IDPs in Africa; and engaging in dialogue with member States, national human rights institutions, relevant intergovernmental and non-governmental bodies, and international and regional mechanisms involved in the promotion and protection of the rights of refugees, asylum-seekers and IDPs. He was also required to submit reports on the situation of refugees, asylum-seekers and IDPs in Africa at every Ordinary Session of the ACHPR. See, for instance, the reports submitted to the 44th and 45th Sessions of the Commission in Abuja (2008) and Banjul (2009). For extensive coverage of the OAU's role in the protection of the displaced, see Bahame Nyanduga, "Refugee Protection under the 1969 OAU Convention Governing Specific Aspects of Refugee Problem in Africa", German Yearbook of International Law, Vol. 47, 2004. 
Nyanduga to tackle the growing challenge of internal displacement, the AU Executive Council adopted a decision requesting the ACHPR to work with its partners and stakeholders, to ensure that IDPs would be provided with an appropriate legal framework which would guarantee their adequate protection and assistance. ${ }^{47}$ This was followed by other decisions in Addis Ababa, Ethiopia, ${ }^{48}$ and in Banjul, Gambia, in June 2006, which called for "the Commission to expedite efforts at finalizing the Draft legal Framework on the Protection and Assistance of Internally Displaced Persons". ${ }^{49}$ These efforts not only recognized the non-binding nature of the Guiding Principles but also reaffirmed the political will and commitment of African countries to negotiate and adopt specific instrument to address the challenge of displacement in Africa. The Guiding Principles were considered insufficient not only because of their non-binding nature but also because they did not provide solutions and accountability for IDP challenges on the continent.

In a broader context it can be argued that the road to Kampala, leading to the adoption of a fully fledged African instrument for the protection of IDPs, was fraught with many challenges. Chief among them was the reluctance of some States to adopt an instrument which they considered unnecessary, as these States felt that the IDP challenge was an exclusive internal issue and that any attempt to adopt legislation to provide for the protection of IDPs would violate the sovereign right of non-interference in domestic affairs. However, many reasons militated in favour of the adoption of the continent-wide instrument. Unlike before, when States were protective of their internal affairs, a progressively significant number of them, especially those hosting large numbers of IDPs, recognized that international cooperation was critical in addressing the IDP challenge, and this contributed to their willingness to participate in multilateral efforts to resolve the matter. ${ }^{50}$ Additionally, the vulnerability of IDPs opens them to manipulation and possible recruitment by armed groups fighting against States; ${ }^{51}$ as such, it was seen as being primarily within the interests of States to exercise protective oversight over such groups of people and to prevent them from falling prey to the whims of ever-proliferating armed groups within their countries.

Nevertheless, it can generally be argued that the AU process which resulted in the adoption of the first binding convention to protect and assist IDPs was a trend-setter not only for demonstrating the full commitment of African States to address the challenge of internal displacement, but also in defining the contours of the international protection regime for IDPs. Despite the fact that the AU instrument adopted and refined some provisions within the 1998 Guiding Principles, the process reaffirmed the widely held belief by the AU that universal 
standards developed under the auspices of the UN have to be enriched by an African understanding of basic rights and protection of IDPs. ${ }^{52}$

\section{Salient features of the 2009 Kampala Convention}

Various efforts - including ministerial declarations, resolutions and Executive Council decisions undertaken and pronounced both at the regional and continental levels by the OAU, the AU and its associated bodies - culminated in the eventual adoption of the AU instrument for the protection of IDPs in Kampala in October 2009.53 The Kampala Convention transformed what had remained "soft law" for more than a decade into "hard law" by clearly articulating the rights and obligations of duty bearers and right holders. ${ }^{54}$ The Kampala Convention treats IDPs as subjects of rights rather than victims of circumstance, while at the same time spelling out the obligations of States as primary duty bearers and identifying roles for other relevant responders. ${ }^{55}$ This Convention is not only the first legally binding instrument at the continental level, but is also the first one that succinctly articulates the rights and duties of IDPs and States. It articulates the general obligations of States relating to the protection and assistance of IDPs, and the obligations of the AU itself, international organizations, armed groups, non-State actors and States Parties, during and after displacement. The Convention further imposes obligations on States to ensure durable solutions for IDPs through sustainable return, local integration or relocation, and to provide compensation as well as ensuring registration and access to personal documentation for all IDPs. The Convention construes sovereignty as a positive obligation, entailing responsibility for the protection and general welfare of citizens and of those falling under the State's jurisdiction. The casting of sovereignty as a State obligation is significant because it means that States cannot abdicate their primary responsibility towards their citizens while hiding under the veil of sovereignty and non-interference in internal matters.

Who, then, is considered an IDP within the meaning of the Kampala Convention? From the outset it should be noted that previous instruments, such as the 1998 Guiding Principles, do not provide a legal definition of an IDP, but

52 P. Tigere and R. Amukhobu, above note 40, p. 49. However, it is important to recall that the first binding IDP instrument was the International Conference of the Great Lakes Region Protocol on the Protection and Assistance to Internally Displaced Persons, 30 November 2006, available at: www.refworld.org/pdfid/ 52384fe44.pdf. This was the first regional step (binding for the twelve States that ratified it) towards the protection and assistance of IDPs. Also, it required member States (at the subregional level) to incorporate the Guiding Principles into their national legislation.

53 Kampala Summit for the African Heads of States and Governments, October 2009. See UNHCR, "African Union Summit", available at: www.unhcr.org/african-union-summit.html.

54 W. Kidane, above note 3, p. 53.

55 See Chaloka Beyani, "The Politics of International Law: Transformation of the Guiding Principles on Internal Displacement from Soft Law into Hard Law", Proceedings of the ASIL Annual Meeting, Vol. 102, 2008, pp. 194-195. 
rather a description of who may be considered as one. ${ }^{56}$ This is because, unlike the case of refugees, the notion of IDPs should not be construed as a legal status. ${ }^{57}$ Adopting the same language as the Guiding Principles, the Kampala Convention therefore defines IDPs as

persons or groups of persons who have been forced or obliged to flee or to leave their homes or places of habitual residence, in particular as a result of or in order to avoid the effects of armed conflict, situation of generalized violence, violations of human rights or natural or human-made disasters, and who have not crossed an internationally recognized State border. ${ }^{58}$

The Convention provides four conditions to merit an individual as an IDP. The person must be fleeing to avoid the effects of armed conflict, situations of generalized violence, violations of human rights, and/or natural or human-made disasters. More crucially, such persons should not have crossed an internationally recognized State border. The Convention neither articulates the status of an individual IDP, nor answers the question of the end of displacement. The noninclusion of a clause which would signify the end of displacement may be attributed to the reluctance of States to commit themselves to something they consider impractical and unnecessary precisely because IDPs are within their own territories. ${ }^{59}$ On the other hand, the Guiding Principles do not define or give circumstances that merit an individual as an IDP; they rather prohibit displacement and spell out State obligations in the event that displacement occurs.

The Kampala Convention goes beyond the traditional causes of displacement such as armed conflicts and human rights violations by recognizing other causes of displacement, such as climate change and project-induced displacement. ${ }^{60}$ This aspect is significant as it is a recognition that with the growing quest for economic and social development, some countries have been willing to displace the population in order to pave way for projects undertaken by multinational corporations and local governments. This provision builds upon the Guiding Principles, which do not go far enough to ensure that there is not only full consultation with people likely to be displaced, but also comprehensive consideration of the social and economic impact of such projects on the wellbeing of the communities concerned.

The Kampala Convention is envisaged to serve as a basis for solidarity, cooperation, the promotion of durable solutions and mutual support between States in order to combat displacement and its consequences, prevent conflict and promote peace and security. ${ }^{61}$ It also provides the obligations and responsibilities

56 Walter Kälin, Guiding Principles on Internal Displacement: Annotations, Studies in Transnational Legal Policy No. 38, American Society of International Law, Washington, DC, 2000.

57 Ibid.

58 Kampala Convention, Art. 1(k).

59 Allehone Abebe, "The African Union Convention on Internally Displaced Persons: Its Codification Background, Scope and Enforcement Challenges", Refugee Quarterly Survey, Vol. 29, No. 3, 2010, p. 51.

60 Kampala Convention, Arts 5(4), 10.

61 Ibid., Art. 2(c). 
of States Parties with respect to the prevention of displacement and assistance of the displaced. ${ }^{62}$ By examining these objectives, it becomes clear that the Convention places a higher premium on solidarity and State cooperation as a basis for addressing the challenge of displacement, and it can be argued this is a recognition that the challenge of IDPs is too huge and complex to be addressed by one country. This reality is reinforced by the fact that most countries experiencing internal displacement, especially in Africa, are politically unstable and are characterized by extreme poverty and weak governance structures, which greatly inhibits their ability to respond to the needs of their populations.

Unlike the Guiding Principles, which approach displacement from the perspective of the rights of IDPs, the Kampala Convention approaches the problem from a State perspective and is intended as a tool for duty bearers, reaffirming the primary role of the State to address the IDP challenge and the complementary roles of other actors. The Guiding Principles reaffirm that IDPs should be treated equally to all other citizens, and prohibit discrimination on the basis of their being internally displaced. The Kampala Convention, for its part, restates the same ethos, but differently. It mandates States to refrain from, prohibit and prevent arbitrary displacement of their populations while at the same time reaffirming the right of IDPs not to be arbitrarily displaced. ${ }^{63}$ In other words, the primacy is put on the duty of States to prevent displacement rather than the right of the population not to be displaced.

The Kampala Convention prohibits arbitrary displacement by specifically listing forms of displacement which may be considered arbitrary. It prohibits displacement based on policies of racial discrimination aimed at or resulting in altering the ethnic, religious or racial composition of the population, and individual or mass displacement of civilians in situations of armed conflict unless there is a need to do so in accordance with IHL. ${ }^{64}$ It also considers displacement intentionally used as a method of warfare caused by generalized violence or violations of IHRL. In what may be viewed as the desire of the negotiators to enrich the Convention with specific cultures and customs practiced on the continent, it recognizes displacement which may occur as a result of "harmful practices". ${ }^{65}$ This refers to practices such as forced circumcision, female genital mutilation and forced marriages, leading individuals fleeing such practices to be recognized as internally displaced and hence in a position to avail themselves of protection and assistance under the Convention.

The Convention also obliges States to prevent political, social, cultural and economic exclusion and marginalization, which are considered to be major causes of

62 Ibid., Art. 2(d).

63 W. Kidane, above note 3, p. 57.

64 Kampala Convention, Art. 4(4).

65 Ibid., Art. 1(j). It may also be argued that the term "harmful practices" mirrors the definition in Article 1 of the Protocol to the African Charter on Human and Peoples' Rights on the Rights of Women in Africa and expands it to cover "all persons" - therefore representing a positive development. This concept is also referred to in Article 21 of the African Charter of the Rights and Welfare of the Child. 
displacement. ${ }^{66}$ The significance of this provision lies in the recognition that more often than not, displacement has been the result of State failure and a breakdown of the rule of law. In contrast to other international instruments dealing with displacement, the Kampala Convention provides for accountability for those who cause displacement. ${ }^{67}$ It is worth noting that some of the responsibilities enshrined in the Convention are owed jointly by States and non-State actors. However, it is also worth asking why the negotiators were keen to impose obligations on non-State actors such as rebel movements or multinational corporations instead of dealing with governments as the primary subjects of international law-making. It can be argued that this decision stemmed from the reality that increasingly, non-State actors such as armed groups play a vital role in the governance of territories to the extent that they perform most functions which are traditionally attributable to States, such as controlling a population in a sovereign State and the imposition and collection of taxes. ${ }^{68}$ It is therefore evident that the provisions were adopted with an objective of ensuring that the protection of IDPs is guaranteed regardless of which actors may be involved in the acts of displacement.

Accountability of non-State actors involved in the exploration and exploitation of economic and natural resources leading to displacement is also enshrined in the Kampala Convention. ${ }^{69}$ The Convention defines armed groups as "dissident armed forces or other organized armed groups that are distinct from the armed forces of the state", while it defines non-State actors as "private actors who are not public officials of the State, including other armed groups ... whose acts cannot be officially attributed to the State". ${ }^{70}$ Armed groups are prohibited from carrying out arbitrary displacement, hindering assistance to the displaced, restricting freedom of movement of IDPs within and outside their area of residence, and impeding humanitarian assistance. ${ }^{71}$ This aspect is critical especially because the 1998 Guiding Principles did not address the issue of accountability for those responsible for causing displacement. Further, the fact that the Guiding Principles were not binding meant that they could not legitimately serve as a framework of accountability for those responsible for causing displacement.

The Kampala Convention designates States as having a primary duty and responsibility to provide protection and humanitarian assistance to IDPs. ${ }^{72}$ Cooperation and solidarity among States may be invoked at the request of the concerned State Party or the Conference of States Parties. The implication of this arrangement is that the Convention does not give exclusive powers to the State

66 Kampala Convention, Art. 3(1)(b).

67 Mike Asplet and Megan Bradley, "Strengthened Protection for Internally Displaced Persons in Africa: The Kampala Convention Comes into Force", ASIL Insights, Vol. 16, No. 36, 2012.

68 See, generally, Allehone Abebe, The Emerging Law of Forced Displacement in Africa: Development and Implementation of the Kampala Convention on Internal Displacement, Routledge, London, 2016.

69 Kampala Convention, Arts 3(1)(h)-(i).

70 Ibid., Arts 1(e), 1(n).

71 Ibid., Art. 7.

72 Ibid., Art. 5(1). 
experiencing displacement to determine whether other countries should be involved in what is essentially a domestic affair. Rather, it empowers the Conference of States Parties to seek such assistance on behalf of the State Party concerned. ${ }^{73}$ This can be distinguished from the Guiding Principles, which, while recognizing the primary role of States to provide protection and humanitarian assistance to IDPs, do not explicitly recognize an obligation of other States to provide humanitarian assistance to IDPs not in their own countries. This can be attributed to the longheld and well-recognized principle of non-interference in the domestic affairs of States. It is therefore evident that the Kampala Convention has enriched the provision to ensure that the IDP challenge is addressed on the basis of international solidarity and cooperation. ${ }^{74}$

It is worth noting that the Convention reaffirms the fundamental principles of humanitarian assistance. This argument is made in light of the fact that States Parties have an obligation to ensure that the humanitarian principles of humanity, neutrality, impartiality and independence are observed and respected. In other words, States are required to refrain from politicizing humanitarian assistance. ${ }^{75}$ International organizations are required to be neutral and independent and to respect the laws of the country in which they are operating. ${ }^{76}$ This requirement is significant given the fact that most organizations, especially those working in areas of human rights, may take it upon themselves to criticize governments if they are responsible for causing displacement. Admittedly, governments are not beyond the confines of international scrutiny when it comes to human rights violations, but humanitarian actors must ensure that they do not condemn States at the expense of IDPs. Ultimately, States can take actions which may directly or indirectly endanger the lives and well-being of the displaced, leaving them in a protection vacuum or at risk of physical harm. ${ }^{77}$

What can be considered as an innovation in the Kampala Convention are special provisions for the protection and assistance of vulnerable groups. These provisions require States Parties to provide special protection for and assistance to IDPs with special needs, including separated and unaccompanied children, female heads of households, expectant mothers, mothers with young children, the elderly, persons with disabilities and those with communicable diseases. ${ }^{78}$ While the Guiding Principles recognize the importance and obligation of providing support to the most vulnerable groups, such as women, the elderly or persons with disabilities, they do not go far enough in imposing these obligations on specific group of actors as has been provided for in the Kampala Convention. ${ }^{79}$ Further, States have an obligation to consult IDPs and to allow them to

77 Miriam Bradley, Protecting Civilians in War: The ICRC, UNHCR, and Their Limitations in Internal Armed Conflicts, Oxford University Press, Oxford, 2016, pp. 130-136.

78 Kampala Convention, Art. 9(2)(c).

79 Ibid., Art. 9(3). 
participate in decisions relating to their protection and assistance. In other words, the Convention recognizes the right of IDPs to be as fully involved as any other citizen and to exercise their civil and political rights such as the right to vote and the right to be elected to public office. The notion of public participation is cardinal, especially taking into account the fact that in most cases IDPs are excluded from enjoying their constitutional rights and duties within their home countries precisely because they are placed in camps where their treatment is similar to that afforded to refugees. ${ }^{80}$

The right of voluntary return, local integration or relocation on a sustainable basis, as part of a comprehensive, durable solution, is guaranteed by the Kampala Convention. ${ }^{81}$ To achieve this objective, States are obliged to ensure that they seek lasting solutions to the problem of IDPs by creating conditions for voluntary return or integrating the displaced with the local population. This aspect of the Convention can be distinguished from the Guiding Principles, which, while recognizing the right to return and reintegration of IDPs, impose the obligation to facilitate the realization of this objective on "competent authorities". ${ }^{82}$ The Kampala Convention, for its part, categorically imposes this obligation on member States working closely with the AU, international organizations and civil society organizations. ${ }^{83}$ It is therefore evident that the Convention has gone the extra mile to identify duty bearers who should facilitate sustainable return and local integration of IDPs. It is also worth mentioning that the Convention establishes a mechanism, through the Conference of States Parties, dedicated to monitoring and reviewing the implementation of its objectives. $^{84}$

\section{The Kampala Convention as a possible model for developing an international legal framework for the protection and assistance of IDPs}

Upon examining the Kampala Convention, it can be argued that the document includes several elements which seem to be groundbreaking in advancing the international protection of IDPs. Specifically, the Convention recognizes the central obligation of States to provide protection and assistance to those displaced

80 M. Rafiqul Islam, "The Sudanese Darfur Crisis and Internally Displaced Persons in International Law: The Least Protection for the Most Vulnerable", International Journal of Refugee Law, Vol. 18, No. 2, 2006, p. 357. See also Ronan McDermott and Pat Gibbons, "Human Rights and Proactive Displacement: Determining the Appropriate Balance between the Duty to Protect and the Right to Remain", Disasters, Vol. 41, No. 3, 2016.

81 Kampala Convention, Art. 11(1).

82 Guiding Principles, Principle 28.

83 Kampala Convention, Art. 11(3).

84 Ibid., Art. 14. The first Conference of States Parties took place in April 2017, in Harare. For details, see "Plan of Action for the Implementation of the Kampala Convention Adopted by Conference of States Parties", press release, 5 April 2017, available at: au.int/en/newsevents/20170403/1st-meetingconference-states-parties-kampala-convention. 
within their own borders. This recognition is not only essential as a reassurance for States that their sovereignty is respected, but also serves as a reaffirmation that States are the primary duty bearers when it comes to the responsibility of protecting their citizens. International assistance may therefore be sought only when States are unable or unwilling to discharge this role. Despite the fact that a significant part of the international community has endorsed and accepted the persuasive authority of the Guiding Principles, these principles are not legally binding. This reinforces the argument that the international community should explore the option of adopting an international legally binding treaty to address the plight of IDPs. This could be undertaken by refining the current Guiding Principles and enriching them with additional rights and duties to make them conform to new realities and developments in international law, which would reflect the current trends of forced displacement. The process would be enriched by ensuring that it is State-led and that the final document is subject to ratification.

Another reason that supports the adoption of an international legally binding instrument stems from the reality that the number of IDPs has, astonishingly, surpassed that of conventional refugees recognized under international law and under the care of UNHCR. ${ }^{85}$ In some countries, like Syria, Yemen, Somalia and Afghanistan, a majority of people have been displaced by armed conflicts between various militias and government forces, with no possibility of enjoying protection without international assistance. In such situations, it is no longer feasible to consider the challenge of internal displacement as an internal matter that can be addressed on an ad hoc basis by applying the 1998 Guiding Principles. Some proponents have argued that creating a new international legally binding instrument on IDPs could lead to the erosion of the existing refugee protection regime. However, it may be argued, this position ignores the fact that despite the view that refugees and IDPs share the same predicament, refugees can be considered a privileged category compared to IDPs. Indeed, once the latter cross the border, they become the responsibility of the international community, such as States that guarantee their safety and agencies like UNHCR which ensure their international protection and search for durable solutions. The situation is different for IDPs - while States are expected to guarantee their protection and safety, it may be the case that those very States are responsible for their predicament in the first place.

Further, the Kampala Convention has dispelled the long-held concern that any new instrument tailored specifically to the needs of IDPs would encounter difficulties in reaching a consensus. The Kampala Convention has proved that it is possible and desirable to have separate instruments addressing different categories of displacement. Having separate instruments for refugees and IDPs recognizes the fundamental difference between the two groups. While refugees have crossed an international border and as such fall under the jurisdiction of a

85 UNHCR estimates that currently there are over 65 million people displaced from their homes. Among this number, more than 40 million are IDPs. See UNHCR, "Figures at a Glance", available at: www.unhcr.org/ figures-at-a-glance.html. 
separate international regime, IDPs are still subject to the laws and protection of their own countries. As such, proponents of having a single instrument for both categories $^{86}$ of displacement conveniently ignore the reality that international attempts to provide protection to IDPs fundamentally challenges States' authority, especially their territorial integrity. As the Kampala Convention has shown, separate instruments that would address two distinct groups can expedite international assistance to both, by clearly allocating the State's obligations towards both refugees and IDPs. In addition, having an international binding IDP instrument would ensure that States bear their share of the burden in the protection of IDPs. As it currently stands, while African countries have adopted a legally binding instrument, most members are not only in a poor economic position to contribute meaningfully towards this objective, but also have significant numbers of IDPs within their countries. It is therefore crucial that the IDP problem is addressed on a basis of solidarity among the international community in order to help lessen the economic and social burden, especially on poor countries.

One must identify the needs of IDPs in order to determine how the law should respond to these needs. Having a universal legally binding instrument for IDPs heralds a sense of responsibility and, significantly, compels States not only to extend international protection to IDPs but also to provide the requisite resources to help alleviate their suffering within their own countries. In other words, having a binding treaty requires compliance by the parties to such instruments. The element of financial assistance is crucial, given the economic and social challenges that characterize the majority of IDP-hosting countries. Indeed, this would also enable even organizations bestowed with a mandate to address the IDP situation to legitimately seek more resources from the international community in order to discharge that mandate. Admittedly, the nexus between resources and mandate has always been a contentious subject because even refugees, whose protection mandate is internationally sanctioned, have had problems attracting the requisite resources. Nevertheless, having an instrument apportioning clear obligations upon States can go the extra mile towards ensuring that countries feel obligated to provide more resources instead of relegating the internal displacement issue to the domestic agenda of concerned countries.

The Kampala Convention compels States to address the problem of internal displacement through solidarity and burden sharing. Clearly, this concept of solidarity and burden sharing can positively contribute to the global view of internal displacement as a challenge whose solution lies in the ability of countries to address the root causes of displacement, which are more often than not economic, social and political. This recognition and acknowledgement would require the international community to extend assistance to address such problems. Also worth noting is that the Convention is substantially innovative in that it recognizes causes of displacement beyond armed conflicts and human 
rights atrocities - it also recognizes climate change, natural disasters and development-induced projects as legitimate bases for displacement. In the wake of Cyclone Nargis and a dithering and intransigent attitude by countries like Myanmar towards accepting international aid, ${ }^{87}$ the presence of a binding international instrument would significantly compel States to honour their international obligations.

Another important element within the Kampala Convention is the question of accountability for those who cause displacement. The Convention acknowledges and recognizes the possibility of holding non-State actors accountable for human rights violations. It requires States Parties to exercise criminal accountability for those who cause displacement. This is a notable achievement in the general development of accountability in international law. ${ }^{88}$ Admittedly, this nature of accountability would be difficult to realize in some cases where States are unable or unwilling to undertake such a role. Nevertheless, the Convention recognizes this gap and makes a provision to the effect that accountability may also be undertaken at the international level. This means that when States are unable or unwilling to exercise criminal accountability domestically, they may ask the International Criminal Court to intervene when and if the Court finds it within its jurisdiction to do so. ${ }^{89}$ This development on the accountability front is a welcome evolution, mainly because private and multinational companies involved in the exploitation of natural resources, especially in conflict-ridden countries, have in some cases caused massive displacement to pave the way for their investment activities, with little scrutiny at either the domestic or international levels. Similarly, the fact that States Parties are required to provide compensation and reparation ${ }^{90}$ for displacement caused could contribute to the need for both State and non-State actors to take into account the plight of those likely to be displaced by involving them in decision-making before undertaking projects that are likely to displace them.

\section{Conclusion}

The Kampala Convention is a ground-breaking instrument. It is the first ${ }^{91}$ binding instrument of its kind at the regional level negotiated and adopted within a multilateral framework of international law-making to address the challenge of internal displacement. It has recognized and broadened varied causes of internal displacement such as natural disasters, armed conflicts, development-induced projects and internal strife, to mention a few. It further recognizes the role of

87 See, generally, A. McCormick, above note 19, pp. 563-565.

88 Phil Orchard, "Regionalizing Protection: AU and ASEAN Responses to Mass Atrocity Crimes against Internally Displaced Persons", Global Responsibility to Protect, Vol. 8, No. 2-3, 2016.

89 See, generally, Kampala Convention, Arts 7(4), 7(5).

90 See, generally, ibid., Art. 12.

91 Note that the first binding subregional instrument on IDPs was the International Conference on the Great Lakes Protocol on IDPs. See above note 52. 
non-State actors, such as armed groups, as the source of displacement without giving these groups any kind of legitimacy for their activities in challenging State authorities in their respective countries. This recognition is made for the purposes of holding these actors individually criminally liable for activities that may breach obligations enshrined in the Convention.

It has also been shown that despite weaknesses and gaps identified within the Convention itself, the Kampala Convention does address the challenges of displacement and provides for the discharge of obligations of all concerned parties including States, IDPs and the international community. This is a welcome development in international law precisely because it demonstrates the willingness of countries to collectively address the challenge of forced displacement by clearly articulating and reaffirming their primary role of preventing displacement of their own citizens. It is argued that the Convention can serve as the basis of a more comprehensive international instrument to address the challenge of IDPs which continues to affect the lives of millions of people across the world.

The ongoing conflicts in Yemen, Syria and elsewhere, and the unprecedented exploitation of natural resources in countries such as the Democratic Republic of the Congo, ${ }^{92}$ continue to significantly contribute to a wave of displacement globally. Based on this reality, the international community should build on regional and international efforts like the Kampala Convention to negotiate a comprehensive legal protection framework for IDPs. This argument is made in light of the fact that, increasingly, countries have recognized that the displacement challenge is no longer a temporary situation - rather, it is a growing problem which requires a permanent solution. Adopting a global legal instrument would be a positive start towards a comprehensive legal and institutional solution to this challenge. 